\title{
Australian Journal of

\section{Nutrients accumulation in black oat (Avena strigosa) and pearl millet (Pennicetum glaucum) after application of herbicides glyphosate or glufosinate-ammonium}

\author{
Virginia Damin*1 ${ }^{1}$ P.C.O. Trivelin ${ }^{2}$ \\ ${ }^{1}$ Escola de Agronomia, Universidade Federal de Goiás (EA/UFG), Av Esperança, sn, CP 131, CEP 74690-900, Goiânia- \\ GO, Brazil \\ ${ }^{2}$ Centro de Energia Nuclear na Agricultura, Lab. Isótopos Estáveis. Av. Centenário, 303 cx.postal 96, CEP 13416-000, \\ Piracicaba-SP, Brazil
}

*Corresponding author: virginia@gmail.com; pcotrive@cena.usp.br

\begin{abstract}
Cover crops used in conservative cropping systems can accumulate large amounts of nutrients, reducing nutrient losses from the soil-plant system and improving the nutrient use efficiency in crops. However, recent researches demonstrated that herbicides used to kill cover crop could decrease $\mathrm{N}$ status in the straw, reducing the nutrient availability to the cash crop. In this context, the aim of this work was to investigate the effect of glyphosate or glufosinate-ammonium application in $\mathrm{K}, \mathrm{P}, \mathrm{Ca}, \mathrm{Mg}, \mathrm{S}$ and $\mathrm{C}$ status in plant's tissues of black oat (Avena strigosa) and peal millet (Pennicetum glaucum) desiccated with herbicides. An experiment was carried out under greenhouse conditions using a factorial design $2 \times 3$. The evaluated factors were cover crop (black oat or peal millet) and cover crop management (1-Control- mechanical cut, without herbicide application; 2-Glyphosate- cover crop desiccation with glyphosate; 3-Glufosinate- cover crop dessication with ammonium-glufosinate). Dry mass production, nutrients accumulation in plants part and entire plants and the nutrient's utilization efficiencies were determined. The nutrients accumulation in plants was not reduced by herbicides; however, a lower dry matter and $C$ accumulation was observed after herbicides application. Glyphosate increased K, P, S and C remobilization from leaves to stalks, but glufosinate did not affect it, suggestion a lower effect of this herbicide in nutrients availability to cash crop. Herbicides did not affect $\mathrm{K}, \mathrm{P}, \mathrm{Ca}, \mathrm{Mg}$ and $\mathrm{S}$ losses from plants, thus the total amount of these nutrients in the system should be not affected by glyphosate or ammonium glufosinate utilization. However, since glyphosate changes these nutrients distribution among plant's parts, increasing nutrients in the stalks and reducing nutrients in the leaves of pearl millet, it may affect nutrient availability to cash crops, since leaves mineralization is faster than stalks mineralization on soil. In this sense, the herbicide application is a practice that should be considered for prediction of nutrients availability in soilplant systems, aiming improve the nutrient's use efficiency.
\end{abstract}

Keywords: postemergence herbicides, macronutrients, Avena strigosa, Penicetum glaucum, cover crops.

\section{Introduction}

In Brazil, Black Oat (Avena strigosa) and Pearl Millet (Pennicetum glaucum) are some of the most used cover crops in conservative cropping systems, as no-tillage. Since they have high dry mass production (Sá, 1996), promoting a good soil coverage (Ros and Aita, 1996, Lara Cabezas et al., 2004) and they have high accumulation of nutrients, these cover crops prevent both soil losses and nutrients leaching (Braz et al., 2004; Fageria 2007). Tropical soils usually have low nutrient holding capacity, which together with heavy rainfall, increases the nutrients leaching potential, resulting in a reduction of nutrient use efficiency in cropping systems (Pacheco et al., 2011).

The nutrient accumulation in cover crops is an important strategy to reduce nutrient losses, since nutrients are released slowly, during the cash crop growth season (Ambrosano et al., 2013). However, many factors can affect nutrient accumulation in cover crops, such as the plant species, plant's stage of development and nutrient supply. Moreover, recent studies demonstrated that the $\mathrm{N}$ content in some plant species could be affected by herbicide application (Manderscheid et al., 2005; Damin et al., 2008, 2010, 2016; Pacheco et al., 2017), reducing the mineralization of cover crop residues and $\mathrm{N}$ availability to the cash crop (Damin et al., 2012), and reducing other important organisms' services (Zaller et I., 2014).

Herbicides are usually used to cover crop desiccation prior to the cash crop sowing. Glyphosate is the most used herbicide in the world (Benbrook, 2016), being used for cover crop desiccation, weed control and pre-harvest application (Benbrook, 2016). Glufosinate-ammonium is also used for these purposes (Shaner, 2014). Herbicide application on cover crops induces senescence and may favor both nutrient losses and remobilization (Pacheco et al., 2017), changing the nutrient status in plants residues and, therefore, the nutrient availability to the cash crop (Damin et al., 2009 and 2012). Moreover, some herbicides, like glyphosate, may changes nutrients availability in plants tissues since it can 
chelate some cations, as $\mathrm{Mn}^{2+}, \mathrm{Cu}^{2+}, \mathrm{Fe}^{3+}, \mathrm{Ca}^{2+}$ and $\mathrm{Mg}^{2+}$; however this process may not occur frequently (Duke, 2012) Studies evaluating herbicide effects on nutrient's status in cover crops are rare and usually focused on $\mathrm{N}$ (Vieneau et al., 2004; Damin et al., 2012). Since the herbicide effect in nutrients status in cover crop is unknow, , the aim of this work was to investigate the effect of glyphosate or glufosinate-ammonium application on Black Oat or peal millet in the nutrient's status $(\mathrm{C}, \mathrm{N}, \mathrm{K}, \mathrm{P}, \mathrm{Mg}, \mathrm{Ca}, \mathrm{S}$ and the $\mathrm{C}: \mathrm{P}$ and $\mathrm{C}: \mathrm{S}$ ratio) on plant's tissues. This results can help to develop management strategies that guarantee a better exploitation of nutrients in conservative systems (as notillage), which can reduce costs and the environmental impacts associated with fertilizers usage.

\section{Results}

\section{Dry mass production and nutrients accumulation in black oat and pearl millet}

The average dry mass production was $56.5 \mathrm{~g}$ per pot (equivalent to $14.8 \mathrm{Mg} \mathrm{ha}^{-1}$ ) for pearl millet and 37.8 per pot (equivalent to $9.9 \mathrm{Mg} \mathrm{ha}{ }^{-1}$ ) for black oat. Glufosinate-ammonium reduced dry mass production in pearl millet and glyphosate reduced it in black oat (Fig 1).

In Pearl millet, potassium (K) and calcium (Ca) accumulation in leaves and stalks did not change after herbicide application (Fig 2). After glyphosate application, phosphorus (P) accumulation in leaves was reduced, following an increase of this nutrient in stalk. Magnesium (Mg) accumulation was higher in leaves after glyphosate application, but it did not modify $\mathrm{Mg}$ accumulation in the stalks. After glyphosate application was observed higher sulphur (S) accumulation in stalks, but no differences were observed in leaves. Both herbicides reduced carbon (C) accumulation in leaves and roots, while no differences were observed in stalks $C$ accumulation. Herbicides application also reduced $\mathrm{K}$ and $\mathrm{Mg}$ accumulation in roots, but it not changes $\mathrm{P}$ and $S$ accumulation in roots. $C a$ accumulation in roots was higher after herbicides application on Pearl millet.

In Black oat, glyphosate or glufosinate-ammonium application enhanced $\mathrm{P}, \mathrm{Ca}$ and $\mathrm{Mg}$ accumulation in shoots, while $\mathrm{S}$ accumulation was increased only in Glyphosate treatment (Fig 3). Both herbicides reduced $C$ amount in shoots. In roots $K, P$, $\mathrm{Mg}, \mathrm{S}$ and $\mathrm{C}$ amount were lower after glyphosate application, probably due root detachment, since the concentration of these nutrients were not decreased by herbicide application (data not showed).

In entire plant of pearl millet, $\mathrm{P}$ and $\mathrm{K}$ accumulation were not affected by herbicides application; while was observed higher $\mathrm{Ca}$ accumulation after glyphosate application and lower $\mathrm{Mg}$ accumulation after glufosinate application (Fig 4). In Black oat, P, $\mathrm{K}$ were increased after glufosinate application and $\mathrm{Ca}$ and $\mathrm{Mg}$ accumulation were increased by both herbicides. In both cover crops, glyphosate reduced the $\mathrm{C}$ accumulation in entire plant, but only in pearl millet glufosinate reduced it. $\mathrm{S}$ accumulation was not affected by herbicides application.

\section{Nutrients ratio (C:P, $C: S)$ and nutrients utilization efficiencies}

Pearl millet accumulated higher amounts of nutrients than black oat. In both cover crops, C:P and C:S from aboveground portion and entire plant ratio were reduced by herbicides application. In roots $C: P$ and $C: S$ ratio were not affected by herbicides (Table 1 ). The efficiency of use of $\mathrm{K}, \mathrm{P}, \mathrm{Ca}, \mathrm{Mg}$ and $\mathrm{S}$ for conversion to dry matter (UTef) was reduced after herbicides application on black oat; while only glyphosate reduced it on Pearl millet. Herbicides did not affect the UTef of $C$ in both cover crops (Fig 5).

\section{Nutrients remobilization index in pearl millet}

The remobilization index (RI) in Control was positive for $\mathrm{K}$ and $P$, since these nutrients accumulation were higher in leaves related to the stalks, while for $\mathrm{Mg}, \mathrm{S}$ and $\mathrm{C}$ were obtained negatives $\mathrm{RI}$, due a lower accumulation of these nutrients in leaves related to the stalks. The glyphosate application reduced the $\mathrm{K}, \mathrm{P} \mathrm{S}$ and $\mathrm{C} \mathrm{RI}$, evidencing that glyphosate changes these nutrients partition in plants; glufosinate-ammonium did not affect RI (Table 2).

\section{Discussion}

Pearl millet accumulated more nutrients than black oat; moreover, it showed a better capacity to convert nutrients in dry mass, i.e. higher utilization efficiency than black oat, except for Mg. In high weathering soils, like Brazilian soils, which have a low cation exchange capacity (CEC), the use of cover crops is an important strategy to improve the nutrient use efficiency since it avoids nutrient losses and provide a slow release of nutrients to the main crop uptake (Pacheco et al., 2011; Oliveira et al., 2002; Braz et al., 2004). Moreover, pearl millet showed a higher dry mass production than black oat, providing a better soil cover and avoiding losses of water.

Except for $\mathrm{C}$, herbicides did not reduce the nutrient accumulation by cover crops; however, it consistently reduced the UTef of $\mathrm{P}, \mathrm{Ca}$ and $\mathrm{Mg}$, evidencing that although nutrient uptake was not immediately blocked, these nutrients were not converted to dry mass after herbicides application. Herbicides also affected $C / P$ and $C / S$, which were reduced, suggesting that the straw mineralization may be accelerated by herbicide application. However, Damin et al., (2009 and 2012) evaluated the mineralization of pearl millet and black oat straw treated with herbicides and concluded that mineralization was decreased by herbicides application; these results were attributed to the increase of $\mathrm{N}$ losses by soil-plant system, since it reduced $\mathrm{N}$ status on cover crops (Damin et al., 2008, 2010).

In both cover crops $\mathrm{Ca}, \mathrm{Mg}$ and $\mathrm{S}$ accumulation in aboveground portion were consistently increased after glyphosate, probably because the nutrients uptake did not stop immediately after the herbicide application. Fernandez et al. (1994) and Fuchs et al. (2002) demonstrated that there is a progressive inhibition of photosynthesis and transpiration, reaching total photosynthetic inhibition five/seven days after glyphosate application.

Both herbicides reduced $C$ accumulation in cover crops; during senescence, the degradation of photosynthetic apparatus is an early event, decreasing photo-assimilate 
Table 1. Carbon - phosphorus $(\mathrm{C} / \mathrm{P})$ and carbon-sulphur $(\mathrm{C} / \mathrm{S})$ ratio in entire plant after herbicides application on Pearl Millet and Black Oat.

\begin{tabular}{lcccc}
\hline Treatments & & Pearl Millet & \multicolumn{2}{c}{ Black Oat } \\
\hline & $\mathrm{C}: \mathrm{P}$ & $\mathrm{C}: \mathrm{S}$ & $\mathrm{C}: \mathrm{P}$ & $\mathrm{C}: \mathrm{S}$ \\
Control & $77.7 \mathrm{a}$ & $76.6 \mathbf{a}$ & $85.9 \mathbf{a}$ & $82.0 \mathbf{a}$ \\
Glyphosate & $65.9 \mathrm{~b}$ & $55.9 \mathbf{b}$ & $67.3 \mathbf{~ b}$ & $61.8 \mathbf{b}$ \\
Glufosinate & $66.4 \mathrm{~b}$ & $56.2 \mathbf{b}$ & $76.2 \mathbf{a b}$ & $76.5 \mathbf{a}$ \\
$\boldsymbol{P}$ & $*$ & $* *$ & $* *$ & $* *$ \\
CV $(5 \%)$ & 17,4 & 15,1 & 11,3 & 15,8 \\
\hline
\end{tabular}

* Means followed by different letters, in columns, differ from each other by Tukey's Test ( $\boldsymbol{\alpha}=0.05)$. ${ }^{*}$ Means followed by different letters, in columns, differ from each other by Tukey's Test $(\boldsymbol{\alpha}=0.01)$. ns = test F not significant.

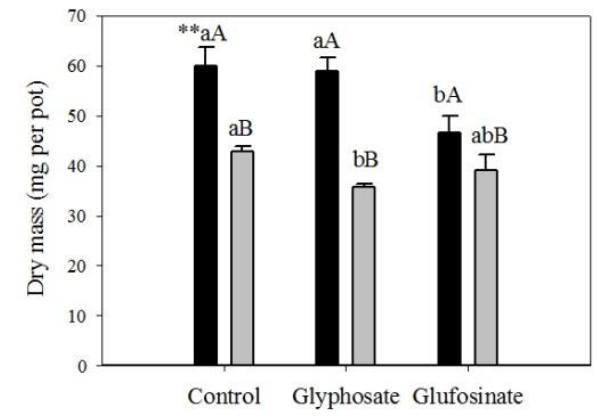

Pearl Millet

Black Oat

Fig 1. Entire plant dry mass after glyphosate and glufosinate-ammonium application on Pearl Millet and Black Oat. ${ }^{* *}=\mathrm{P}<0.01$.

Table 2. Nutrients remobilization index after herbicides application on Pearl Millet.

\begin{tabular}{lcccccc}
\hline Treatment & $\mathrm{K}$ & $\mathrm{P}$ & $\mathrm{Ca}$ & $\mathrm{Mg}$ & $\mathrm{S}$ & $\mathrm{C}$ \\
\hline Control & $0.11 \mathrm{a}$ & $0.18 \mathrm{a}$ & $0.32 \mathrm{a}$ & $-0.33 \mathrm{a}$ & $-0.28 \mathrm{a}$ & $-0.04 \mathrm{a}$ \\
Glyphosate & $-0.24 \mathrm{~b}$ & $-0.12 \mathrm{~b}$ & $0.24 \mathrm{a}$ & $-0.24 \mathrm{a}$ & $-0.46 \mathrm{~b}$ & $-0.21 \mathrm{~b}$ \\
Glufosinate & $0.12 \mathrm{a}$ & $0.16 \mathrm{a}$ & $0.30 \mathrm{a}$ & $-0.27 \mathrm{a}$ & $-0.21 \mathrm{a}$ & $-0.09 \mathrm{a}$ \\
$P$ & $* *$ & $* *$ & $\mathrm{~ns}$ & $\mathrm{~ns}$ & $*$ & $* *$
\end{tabular}

${ }^{*}$ Means followed by different letters, in columns, differ from each other by Tukey's Test $(\boldsymbol{\alpha}=0.05) .{ }^{* *}$ Means followed by different letters, in columns, differ from each other by Tukey's Test $(\boldsymbol{\alpha}=0.01)$. ns = test F not significant.
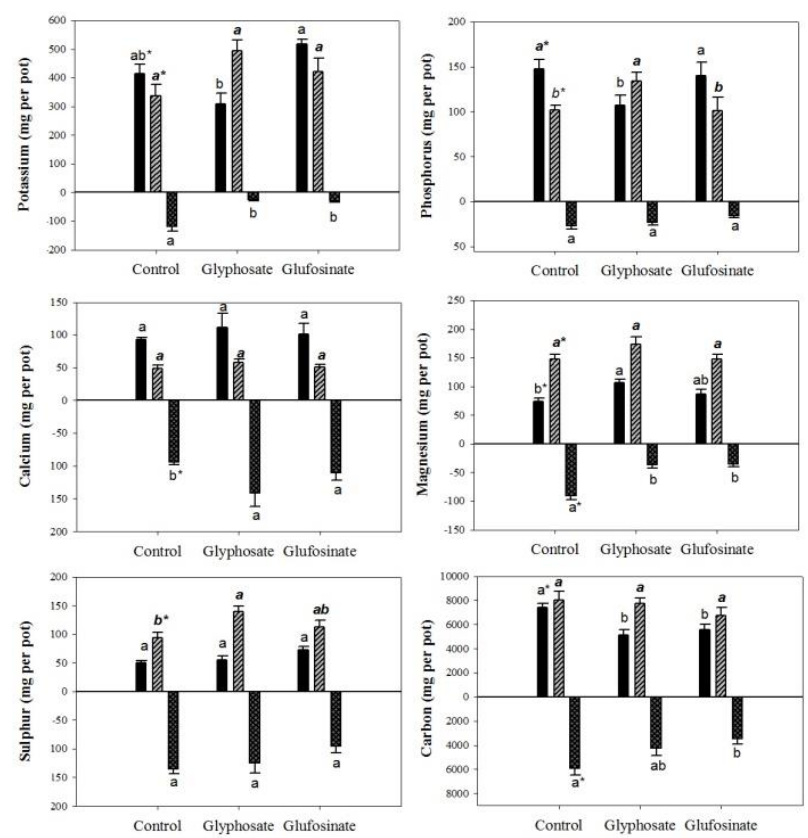

\section{Leaves MIV Stalk}

Roots

Fig 2. Nutrient accumulation in leaves, stalks or roots of Pearl Millet after glyphosate or glufosinate-ammonium application. $* *=\mathrm{P}<0.01$ and ${ }^{*}=\mathrm{P}<0.05$. 

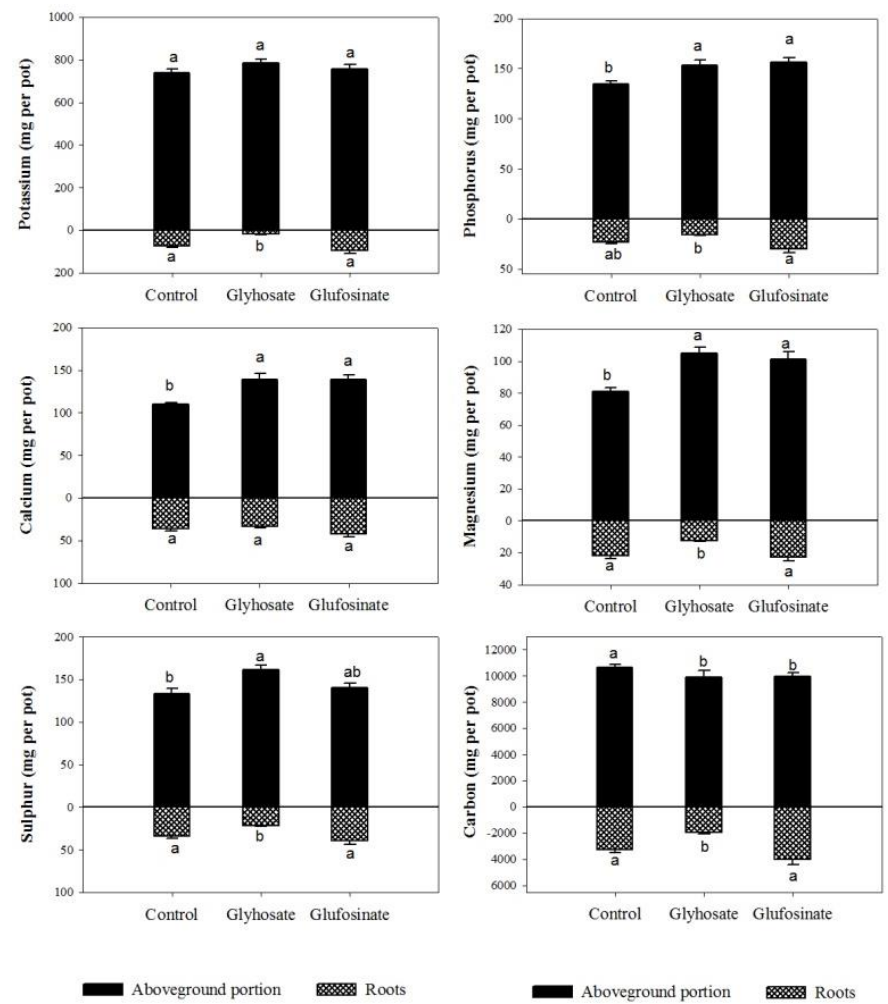

Fig 3. Nutrient accumulation in aboveground portion and roots of Black Oat after glyphosate or glufosinate-ammonium application. ${ }^{* *}=\mathrm{P}<0.01$ and ${ }^{*}=\mathrm{P}<0.05$
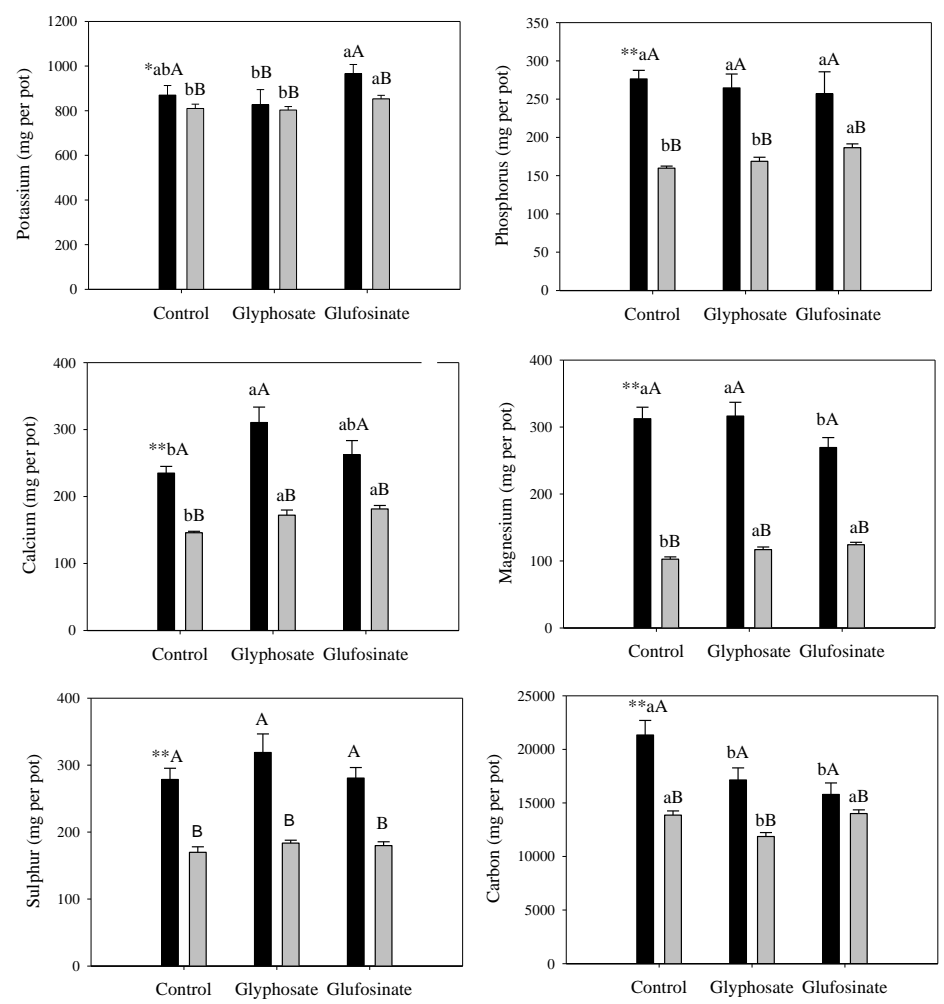

Pearl Millet

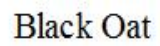

Pearl Millet

Black Oat

Fig 4. Nutrient accumulation in entire plant of Pearl Millet and Black Oat after glyphosate or glufosinate-ammonium application. ${ }^{* *}=\mathrm{P}<0.01$ and ${ }^{*}=\mathrm{P}<0.05$ 

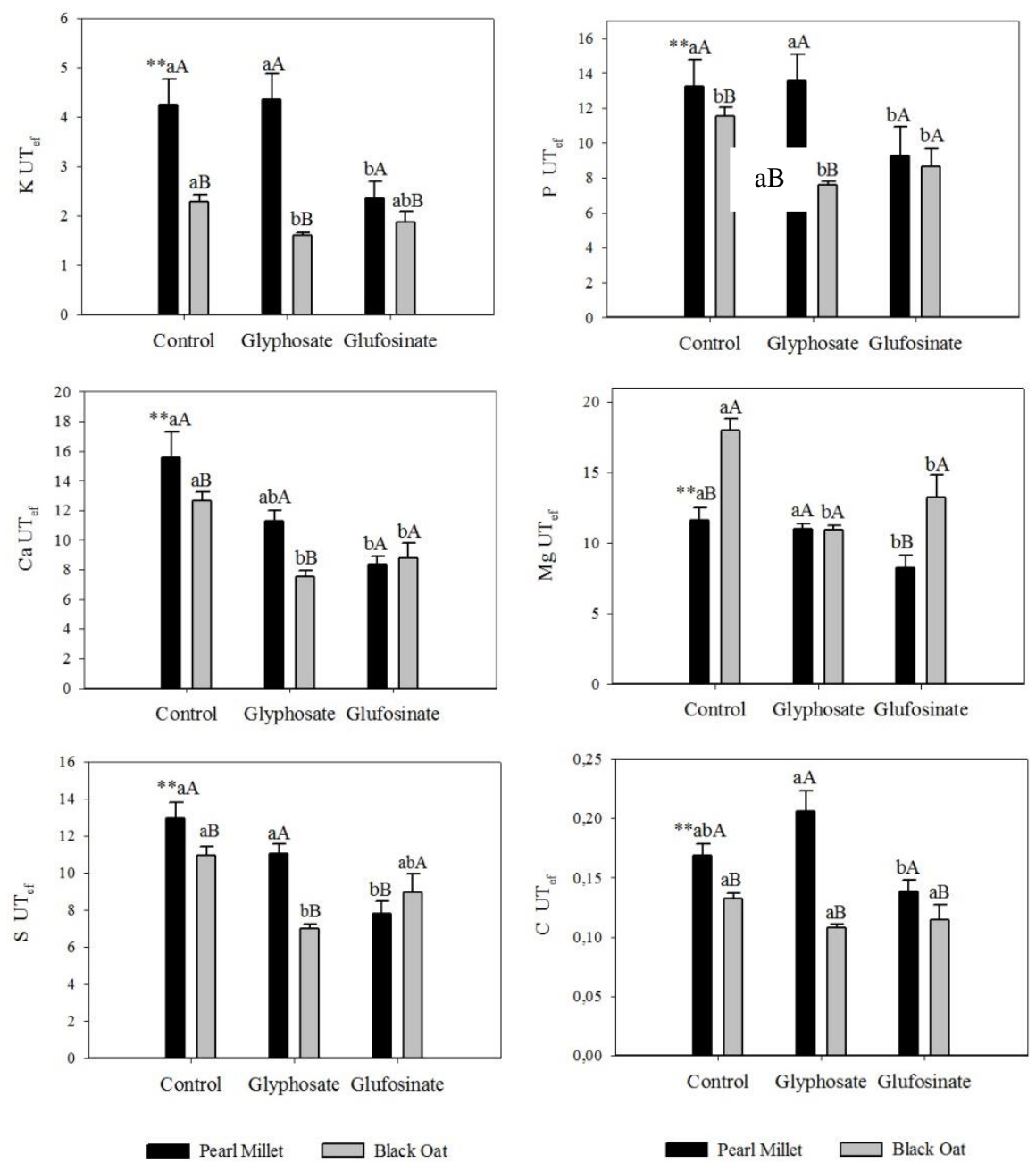

Fig 5. Efficiency of use of nutrients for conversion to dry mass (UTef) of Pearl Millet and Black Oat after glyphosate or glufosinateammonium application. ${ }^{* *}=\mathrm{P}<0.01$ and ${ }^{*}=\mathrm{P}<0.05$

production and increasing the exportation of $\mathrm{C}$ to sinks (Lemoine et al., 2013)

In pearl millet, $\mathrm{C}, \mathrm{K}, \mathrm{P}$ and $\mathrm{S}$ were remobilized from leaves to stalks after glyphosate application, as demonstrated by the remobilization index. Macronutrients except for Ca (i.e., N, $\mathrm{P}, \mathrm{S}, \mathrm{K}$, and $\mathrm{Mg}$ ) are known to be highly mobile in the phloem (White, 2012). In A. thaliana, the K, P and $\mathrm{S}$ levels in leaves drop up to $40 \%$ during senescence $s$ (Himelblau and Amasino, 2001). Potassium forms only week complexes that are easily exchangeable. In fact, many studies reported $\mathrm{K}$ remobilization in significant quantities from senescing tissues (Tyler, 2005). There are no many studies evaluating the amount of $P$ remobilized from senescing tissues, however, Snapp and Lynch (1996) demonstrated that more than $a$ half of the $P$ in bean seeds came from $P$ remobilization from senescing leaves. Sulphur remobilization has been shown in the literature; however, the extent of this process may change with some factors, such as $\mathrm{N}$ status and plant's species (White, 2012).

Even though glyphosate increased these nutrients remobilization in pearl millet, glufosinate-ammonium did not modify it. Photosynthesis is rapidly inhibited by glufosinate-ammonium. Kempenaar et al., (2010) comparing the effect of some herbicides in photosynthesis showed that only 2 days after glufosinate-ammonium application the photosynthesis rates were drastically reduced; they also investigated the glyphosate effect on it and observed that photosynthesis rates declined 4 days after herbicide application. In fact, injury symptoms following treatment with glyphosate are often slow in developing, so plants may be metabolically active during more time after glyphosate than glufosinate-ammonium application.

Unsurprising, $\mathrm{Ca}$ accumulation was increased and $\mathrm{Ca}$ remobilization was not affected after herbicides application, since this nutrient is the least mobile of all macrunutrients (White, 2012). Magnesium remobilization was not observed as well, despite the fact that this nutrient is considered moderate phloem mobile (Maillard et al., ,2015). Similar results were observed by Killingbeck, (2004), who demonstrated that there is a tendency of accumulation of Mg during leaves senescence. In fact, Maillard et al., (2015) reported that $\mathrm{K}, \mathrm{P}, \mathrm{S}$, and $\mathrm{Mg}$ remobilization can be highly dependent of plant's species.

The results obtained in this research demonstrated that had a reduction on dry mass content and some changes in nutrient partition in cover crops after glyphosate application; however only $\mathrm{C}$ accumulation was reduced in pearl millet after herbicides application, which should not 
affect the cover crops capacity to provide nutrients to the cash crop.

\section{Materials and Methods}

\section{Experimental condition and design}

An experiment was carried out under greenhouse conditions, at Centro de Energia Nuclear na Agricultura (CENA/USP), Piracicaba, SP. The experiment was developed between August and November when the temperature ranged from 17 to $27^{\circ} \mathrm{C}$, and with $13 \mathrm{~h} / 11 \mathrm{~h}$ day/night cycles provided by natural sources.

A completely randomized design (CRD) was adopted, in a $3 \times 2$ factorial scheme, with 3 cover crops management conditions (Control: mechanical cut, without herbicide application, Glyphosate: cover crops desiccation with glyphosate and Glufosinate: cover crops desiccation with glufosinate-ammonium) and two cover crops (pearl millet or black oat), with 8 replicates per treatment.

Each pot was filled with $7 \mathrm{~kg}$ of soil from a 0-0.2 layer of a Quatzpsamment (Soil taxonomy, 2006) soil, with $122 \mathrm{~g} / \mathrm{kg}$ of clay, $8 \mathrm{~g} / \mathrm{kg}$ of silt, and $870 \mathrm{~g} / \mathrm{kg}$ of sand. The chemical properties were determined according to Raij et al. (2001) and included the following: $\mathrm{pH}=4.1,0 . \mathrm{M} .=4.0 \mathrm{~g} / \mathrm{kg}, \mathrm{CEC}=3.2$ $\mathrm{cmol}_{\mathrm{c}} / \mathrm{dm}$, base saturation $=21.8 \%$, aluminum saturation= $25 \%, P=1.0 \mathrm{mg} \mathrm{kg}^{-1}$ and $\mathrm{S}=7 \mathrm{mg} \mathrm{kg}^{-1}$. Before sowing, soil acidity and fertility was corrected using $3.5 \mathrm{~g}$ per pot of lime, $100 \mathrm{mg}$ pf $\mathrm{P}$ per $\mathrm{kg}$ of soil and $100 \mathrm{~mL}$ per pot of a solution containing $800 \mathrm{mg}$ of potassium, $0.12 \mathrm{mg}$ of zinc, $0.06 \mathrm{mg}$ of $\mathrm{B}$ and $0.08 \mathrm{mg}$ of $\mathrm{Cu}$. Then, soil humidity was corrected to $70 \%$ of the maximum soil water retention capacity and pots were incubated for 15 days

At the end of the incubation period, 40 seeds of Black Oat and 5 of Pearl Millet were manually seeded in each pot. After germination, the seedlings were thinned in order to have 30 plants per pot of Black Oat or one plant per pot of millet. Then, ammonium sulfate was applied at a rate of 100 $\mathrm{mg}$ per kg of soil. Daily irrigations were performed and the soil moisture was kept at approximately $60 \%$ of the maximum water retention.

At the pre-flowering stage (less than $5 \%$ of panicle emission), control plots were harvested (aboveground part was cutted near to the soil surface and roots were separated from soil and washed) and herbicide application was performed. Glyphosate was applied at a rate of $4 \mathrm{~L} / \mathrm{ha}$ ( $480 \mathrm{~g}$ of a.i. per L), using the Roundoup ${ }^{\circledR}$ formulation; and glufosinateammonium was applied at a rate of $2 \mathrm{~L} / \mathrm{ha}$ ( $200 \mathrm{~g}$ de i.a. per L) using the commercial formulation Finale ${ }^{\circledR}$. The directed herbicide applications were performed with a $\mathrm{CO}_{2}$ pressurized backpack sprayer equipped with a $2 \mathrm{~m}$-wide boom and four flat-fan nozzles.

Pots from Glyphosate and Glufosinate treatments were harvested 13 days after herbicide application, when plants died. The aboveground portion was cut off, and then Pearl Millet aboveground was separated into leaves and stalks. The soil was sieved ( $2 \mathrm{~mm}$-mesh) to separate the roots. Roots were washed to remove soil excess, and then the plant's tissues were oven-dried at $65 \%$ to measure the dry mass (DM). The $\mathrm{K}, \mathrm{P}, \mathrm{Ca}, \mathrm{Mg}, \mathrm{S}$ and $\mathrm{C}$ accumulation was measured according to Malavolta et al., (1997).

The efficiency of use of nutrient for conversion to dry mass (UTef) was calculated by the expression:
UTef $=\frac{\text { total dry mass production }(g \text { per pot })]^{2}}{\text { total nutrient accumulation (mg per pot) }}$

The remobilization index (RI) was calculated by the expression:

$R I=\underline{\text { (nutrient accumulation in leaves }- \text { nutrient accumulation in stalks (mg per pot) }}$ nutrient accumulation in above ground portion ( $\mathrm{mg}$ per pot)

The data values obtained were compared by Tukey's test $(\alpha=0.05)$, using the statistical program $R$.

\section{Conclusion}

Herbicides do not affect $\mathrm{K}, \mathrm{P}, \mathrm{Ca}, \mathrm{Mg}$ and $\mathrm{S}$ losses from plants, thus the total amount of these nutrients in the system should be not affected by glyphosate or ammonium glufosinate utilization. However, since glyphosate changes these nutrients distribution among plant's parts, increasing nutrients in the stalks and reducing nutrients in the leaves of pearl millet, it may affect nutrient availability to cash crops, since leaves mineralization is faster than stalks mineralization on soil. In this sense, the herbicide application is a practice that should be considered for prediction of nutrients availability in soil-plant systems, aiming improve the nutrient's use efficiency.

\section{Acknowledgement}

We are grateful to $\mathrm{CNPq}$, which provided the financial support necessary to the development of this research

\section{References}

Ambrosano EJ, Cantarella H, Ambrosano GMB, Rossi F, Trivelin PCO, Dias FLF, Muraoka T (2013) The role of green manure nitrogen use by corn and sugarcane crops in Brazil. Agri Sci. 4:89-108.

Benbrook CM (2016) Trends in glyphosate herbicide use in the United States and globally. Environ Sci Eur. 28: 3.

Braz AJBP, Silveira PM, Kliemann HJ, Zimmermann FJP (2004) Nutrient accumulation in leaves of millet, brachiaria and guineagrass. Agri Res Trop, 34:83-87.

Damin V, Franco HCJ, Moraes MF, Franco A, Trivelin PCO (2008) Nitrogen loss in Brachiaria decumbens after application of glyfosate or glufosinato-amonnium. Sci Agri. 65:402-407.

Damin V, Trivelin PCO, Franco HCJ, Barbosa TG (2010) Nitrogen $\left({ }^{15} \mathrm{~N}\right)$ loss in soil-plant system after herbicide application in Pennisetum glaucum. Plant Soil. 328:245-252.

Damin V, Trivelin PCO, Trivelin, Bonassi J, Vitti AC (2016) Emissions of ammonia following glyphosate application on Urochloa decumbens. Plant, Soil and Environ. 62: 67-473.

Duke, SO, Lydon J, Koskinen WC, Moorman TB, Chaney RL, Hammerschmidt R (2012) Glyphosate Effects on Plant Mineral Nutrition, Crop Rhizosphere Microbiota, and Plant Disease in Glyphosate-Resistant Crops. J Agric Food Chem. 60: 10375-10397

Fageria NK (2007) Green manuring in crop production. J Plant Nutr. 30:691-719. 
Damin V, Trivelin PCO, Barbosa TG, Carvalho SJP, Moraes MF (2012) Mineralization and corn recovery of ${ }^{15}$ nitrogen from Black Oats residues treated with herbicides. J Plant Nutr. 35:1830-1842.

Feller U, Fischer A (1994) Nitrogen metabolism in senescing leaves. Crit Rev Plant Sci. 13:241-273.

Fernandez CJ, Mcinnes KJ, Cothren JT (1994) Carbon balance, transpiration and biomass partitioning of glyphosate-treated wheat (Triticum aestivum) plants. Weed Sci. 42:333-339.

Fuchs MA, Geiger DR, Reynolds TL, Bourque JE (2002) Mechanisms of glyphosate toxicity in velvetleaf (Abutilon theophrasti medikus). Pest Bio Phys. 74:27-39

Himelblau E, Amasino RM (2001) Nutrients mobilized from leaves of Arabidopsis thaliana during leaf senescence. J Plant Physiol. 158:1317-1323.

Kempenaar C, Lotz LAP, Snel JFH, Smutny V, Zhang HJ (2010) Predicting herbicidal plant mortality with mobile photosynthesis meters. Weed Res. 51:12-22.

Killingbeck KT (2004) Nutrient resorption. In: Plant Cell Death Processes (ed.Nood'en, L.D.). Elsevier Academic Press, Amsterdam, pp.215-226.

Lara Cabezas WAR, Alves BJR, Urquiaga S, Santana DG (2004) Influência da cultura antecessora e da adubação nitrogenada na produtividade de milho em sistema plantio direto e solo preparado. Rural Sci. 34: 1005-1013.

Lemoine R, La Camera $S$, Atanassova R, Dédaldéchamp $F$, Allario T, Pourtau N, Bonnemain JL, Laloi M, CoutosThévenot $P$, Maurousset $L$, Faucher $M$, Girousse $C$, Lemonnier P, Parrilla J, Durand M (2013) Source-to-sink transport of sugar and regulation by environmental factors. Front in Plant Sci. 4: 272

Maillard A, Diquélou S, Billard V, Laîné $P$, Garnica $M$, Prudent M, Garcia-Mina JM, Yvin JC, Ourry A (2015) Leaf mineral nutrient remobilization during leaf senescence and modulation by nutrient deficiency. Front Plant Sci. 6: 317.

Malavolta E, Vitti GC, Oliveira SA (1997) Avaliação do estado nutricional de plantas. 2.ed. Piracicaba: Potafos, 1997. 319 p.

Manderscheid R, Schaaf S, Mattsson M, Schjoerring JK (2005) Glufosinate treatment of weeds results in ammonia emission by plants. Agri Ecosyst Environ. 109: 129-140.

Marshner H (1995) Mineral nutrition of higher plants. London, UK: Academic Press.
Pacheco LP, Barbosa JM, Leandro WM, Machado PLOA, Assis RL, Madari BE, Petter FA (2011) Biomass production and nutrient cycling of cover crops in upland rice and soybean. Braz J Soil Sci. 35:1787-1799 (in Portuguese).

Raij B Van, Andrade JC, Cantarella H, Quaggio JA (2001) Análise química para avaliação da fertilidade de solos tropicais. Campinas: Instituto Agronômico, 285p.

Ros AO, Aita C (1996) Winter cover crops and their nitrogen supply to corn in no-tillage system. Braz J Soil Sci. 20: 135140 (in Portuguese).

Sa JCM (1996) Nitrogen Management for Corn Crop under NoTill System. Passo Fundo, Brazil: Aldeia Norte (in Portuguese).

Shaner DL (2014) Herbicide Handbook. 10th Edition, Weed Science Society of America, Lawrence, $513 \mathrm{p}$.

Snapp SS, Lynch JP (1996) Phosphorus distribution and remobilization in bean plants as influenced by phosphorus nutrition. Crop Sci. 36:929-935.

Soil Taxonomy (2006) Keys to Soil Taxonomy by Soil Survey Staff, 10th ed. United States Department of Agriculture Natural Resources Conservation Service.

Tyler G (2005) Changes in the concentrations of major, minor and rare-earth elements during leaf Senescence and decomposition in a Fagus sylvatica forest. Forest Ecol Manag. 206: 167-177.

Vienneau DM, Sullivan CA, House SK, Stratton GW (2004) Effects of the herbicide hexazinone on nutrient cycling in a low-pH blueberry soil. Environ Toxicol. 19:115-22.

Zaller JG, Heigl F, Ruess L, Grabmaier A (2014) Glyphosate herbicide affects belowground interactions between earthworms and symbiotic mycorrhizal fungi in a model ecosystem. Sci Report. 4: 5634.

White $P$ (2012) Long-distance transport in the xylem and phloem. In Marschner's Mineral Nutrition of Higher Plants, 3rd Edn., ed P. Marschner (Berlin: Elsevier), 49-70. 